\title{
Yield Gap Analysis for Chickpea (Cicer arietinum Linn) Through Cluster Front Line Demonstration under NFSM Scheme in Barmer District of Rajasthan, India
}

\author{
Shayam Das, Pradeep Pagaria*, B.R. Morwal and Manpreet Singh \\ Krishi Vigyan Kendra, Danta-Barmer-I (Rajasthan), India \\ *Corresponding author
}

\begin{tabular}{|c|}
\hline Keywords \\
\hline $\begin{array}{l}\text { Chickpea (Cicer } \\
\text { arietinum Linn), } \\
\text { NFSM, Cluster }\end{array}$ \\
\hline Article Info \\
\hline $\begin{array}{l}\text { Accepted: } \\
04 \text { August } 2018 \\
\text { Available Online: } \\
\text { 10 September } 2018\end{array}$ \\
\hline
\end{tabular}

A B S T R A C T

Enhancing the production potential and socio economic level of farmers, 126 cluster front line demonstration on chickpea laid out during the year 2015-16 to 2017-18. Area under the demonstration was 90 hectare comprising126 farmer of three villages Nagarda and Bhiyar from Sheo block and Gandhavkhurd from Gudamalani block of Barmer District in Rajasthan. Under the cluster approach for technology dissemination programme recommended intervention i.e. high yielding variety, integrated nutrient management and integrated disease and pest management were attempted. Recommended practice recorded mean yield of $11.94 \mathrm{q} / \mathrm{ha}$, which was 28.64 percent higher over the farmer practices $(9.31$ q/ha). Additional cost under the intervention of Rs1992 to 3942 gave additional return of Rs. 6245 to 10421 per hectare. Higher side benefit: cost ratio $(1.52-2.10)$ was recorded during the study period. The extension gap was observed between 2.11 to $3.08 \mathrm{q} / \mathrm{ha}$, technology gap was observed 8.99 to $13.08 \mathrm{q} / \mathrm{ha}$, whereas technology index 37.46 to 54.50 percent. The favorable benefit ratio exhibited the feasibility of technology demonstrated. Therefore, cluster front line demonstration programme was an effective tool for increasing the productivity of chickpea and changing knowledge, attitude and skill of farmers. This created greater awareness and motivated the other farmers to adopt improved practices of chickpea.

\section{Background and objectives}

Oilseed and pulses are the integral part of human diet as they are rich sources of proteins and quality nutrition. Chickpea (Cicer arietinum Linn) is a major pulse crop being grown in India occupies 38 percent area (25.26 million hectares) and 50 percent of the total pulse production (16.47 million tonnes) Anonymous (2016). It is being grown all around the country except high altitude of
Northern, North eastern regions and costal peninsula, Madhya Pradesh, Rajasthan, Maharashtra, Uttar Pradesh, Andhra Pradesh, Karnataka, Gujarat, Chhattisgarh, Haryana, Bihar, Orrisa and West Bengal are the major producing state sharing over 95 percent area. The area, production and productivity of the chickpea in the country is 8.35 million hectare, 7.17 million tones and $8.59 \mathrm{q} / \mathrm{ha}$, respectively. Similarly area, production and productivity of the chickpea in Rajasthan accounting 1.37 million hac, 1.68 million tons 
and $12.28 \mathrm{q} / \mathrm{ha}$ (IIIrd advance estimate Rajasthan 2017-18). Area under chick pea in Barmer recorded 2014hectare producing 1834 tonnes with productivity of $9.11 \mathrm{q} / \mathrm{ha}$ (Raj Krishi 2016-17). Average productivity of chick pea in Barmer district was noticed lower side $(9.11 \mathrm{q} / \mathrm{ha})$ than the average potential yield (22.00 q/ ha). Through survey, farm diagnostic visit and farmers meeting it was realized that the reason behind the lower productivity was due to lack of improved variety, no seed treatment, imbalance use of inorganic fertilizers, lack of knowledge about IPM practices etc. Among the biotic stress, the gram pod borer is a major pest occurring for 75 per cent pod damage in the crop (Krishan Kant et al., 2007). To combat the causes of yield reduction and technology gap, dissemination of recommended technologies of chickpea through cluster front line demonstration were organized at farmer's field during 2015 -16 to 2017-18.

\section{Materials and Methods}

The present study was carried out by Krishi Vigyan Kendra, Barmer-I during Rabi season from 2015-16 and 2017-18 in the farmer's field of three villages Nagarda and Bhiyar from Sheo block and Gandhavkhurd from Gudamalani block of Barmer District. Total of 126 front line demonstrations on chickpea were laid out comprising 126 farmers covering the total area of 90 ha with demonstration plots ranging from 0.40 to $0.80 \mathrm{ha}$. Under the cluster front line demonstrations improved technologies included improved variety (cv. RSG-895 \& RSG-896 during 2015-16 and GNG-1581 during 2016-17 and 2017-18), integrated nutrient management (20: 40: $0 \mathrm{~kg}$ N: P: K/ha) +Rhizobium + P.S.B. @ 600 g per ha, integrated pest management (Deep ploughing + seed treatment with Trichoderma viridi + pheromone trap @ 6/ha + Spinosad $190 \mathrm{ml} / \mathrm{ha}$ ) were tested as intervention. Crop was sown between 20 October to first week of
November with a spacing of $30 \mathrm{~cm} \mathrm{X} 10 \mathrm{~cm}$ and seed rate $70 \mathrm{~kg} / \mathrm{ha}$. Entire dose of $\mathrm{N}$ and $\mathrm{P}$ was applied as basal dose at the time of sowing. Under the demonstration programme farmer practice was maintain as control. Prior to conducting the front line demonstrations, group meeting and specific skill trainings were conducted. All other steps like farmer selection, site selection, farmer's participation etc was followed as suggested by Kirar et al., (2004). Three villages Nagarda and Bhiyar from Sheo block and Gandhavkhurd from Gudamalani block of Barmer District

Farmer practice constituted no deep ploughing during summer, use of old or local variety, with higher seed rate $80-100 \mathrm{~kg} / \mathrm{ha}$, no seed treatment, no bio-fertilizer and indiscriminate use of inorganic fertilizer (9:23:0 NPK kg/ha). All other production and plant protection technologies except the interventions were followed in similar manner in recommended as well in farmer's practices. The yield data were collected from both the demonstration and control plots. The collected data were analyzed using simple tabular analysis like percentage etc. The yield data were collected from both the demonstration and farmer's practices and their technology gap, extension gap, and technology index were a workout as given below (Samui et al., 2000).

Technology gap =Potential yieldDemonstration yield

Extension gap =Demonstration yield Farmer's yield

Technology index $=\{($ Potential yield Demonstration yield) $\}$ / Potential yield x 100

\section{Results and Discussion}

The gap between the recommended practices and existing farmer practices under chick pea is presented in Table 1. Full gap was observed 
in case of variety, seed rate, seed treatment and partial gap was observed in fertilizer and plant protection.

\section{Yield}

The yield of chickpea obtained over the year under improved technology as well as local check is presented in Table 2. The productivity of chickpea ranged from 9.90 to $15.01 \mathrm{q} / \mathrm{ha}$ with mean yield of $11.94 \mathrm{q} / \mathrm{ha}$ under improved technology on farmers field as against a yield ranged from 7.79 to $11.93 \mathrm{q} / \mathrm{ha}$ with a mean of $9.31 \mathrm{q} /$ ha recorded under farmers practice.

The higher productivity was found in the recommended practices as compared to farmer practice during reporting period, which might be due to continuous use of IPNM (Integrated Pest and Nutrient Management) practices. The higher yield of chickpea under recommended practices was due to the use of latest high yielding variety, integrated nutrients management and pest management. Similar results have been reported by Verma (2013).

\section{Economic}

The input and output prices of commodities prevailed during each year of demonstration were taken for calculating cost of cultivation, net return and benefit cost ratio (Table 3 ). The net return from recommended practices was Rs. 15355 to Rs. 27998 while the net return from farmer practices was Rs. 9110 to Rs. 17793. It means that net return from demonstration was higher than the farmer practices. The additional cost of Rs. 1992 to3942 gave additional net return, it ranged Rs. 6245 to Rs. 10421 per hectare. The increase benefit: cost ratio was also calculated, it ranged from 1.52 to 2.10.Thus, and it was clearly showed that the demonstration of chickpea with full package was better than farmer's practices. Similar result has been reported by earlier by Teggelli et al., (2015).

Table.1 Difference between recommended practices and existing farmer practices under chickpea CFLD

\begin{tabular}{|c|c|c|c|}
\hline Crop operations & Recommended practices & Farmers practice & Gap \\
\hline Variety & $\begin{array}{l}\text { GNG-1581, GNG-1958, RSG-974, RSG- } \\
895, \text { RSG-896 }\end{array}$ & $\begin{array}{l}\text { Local or old } \\
\text { variety }\end{array}$ & Full gap \\
\hline Seed rate $(\mathrm{kg} / \mathrm{ha})$ & 70 & $80-100$ & Full gap \\
\hline Soil treatment & $\begin{array}{l}\text { Trichoderma viridae @ } 2.5 \text { kg enriched } \\
\text { with } 100 \mathrm{~kg} \text { FYM }\end{array}$ & No soil treatment & Full gap \\
\hline Seed Treatment & Carbendazim @2.5g/kg seed & No seed treatment & Full gap \\
\hline $\begin{array}{l}\text { Fertilizer dose } \\
(\mathrm{kg} / \mathrm{ha})\end{array}$ & $\begin{array}{l}\text { NPK (20:40:0) Rhizobium and PSB @ } \\
600 \mathrm{~g} / \mathrm{ha}\end{array}$ & DAP 50 & $\begin{array}{l}\text { Partial } \\
\text { gap }\end{array}$ \\
\hline Sowing method & $30 \times 10 \mathrm{~cm}$ row to row and plant to plant & Line sowing & Nil \\
\hline Plant protection & $\begin{array}{l}\text { IPM module (Pheromone trap 6/ha + } \\
\text { Spinosad @ 190ml/ ha }\end{array}$ & $\begin{array}{l}\text { One spray of } \\
\text { insecticide }\end{array}$ & $\begin{array}{l}\text { Partial } \\
\text { gap }\end{array}$ \\
\hline
\end{tabular}


Table.2 Productivity, extension gap, technology gap and technology index of chickpea as grown under FLD and existing package of practices

\begin{tabular}{|c|c|c|c|c|c|c|c|c|c|}
\hline \multirow[t]{2}{*}{ Year } & \multirow[t]{2}{*}{ Area } & \multirow{2}{*}{$\begin{array}{l}\text { No. of } \\
\text { Demo } \\
\text {. }\end{array}$} & \multirow{2}{*}{$\begin{array}{c}\text { Average } \\
\text { potential } \\
\text { yield }\end{array}$} & \multicolumn{2}{|c|}{ Yield q/ha } & \multirow{2}{*}{$\underset{\%}{\text { Impact }}$} & \multirow{2}{*}{$\begin{array}{l}\text { Extension } \\
\text { gap } \\
\text { (q/ha) }\end{array}$} & \multirow{2}{*}{$\begin{array}{c}\text { Technolog } \\
\text { y gap } \\
\text { (q/ha) }\end{array}$} & \multirow{2}{*}{$\begin{array}{c}\text { Techn } \\
\text { ology } \\
\text { Index } \\
(\%)\end{array}$} \\
\hline & & & & $\mathrm{RP}$ & FP & & & & \\
\hline 2015-16 & 20 & 25 & 20 & 9.9 & 7.79 & 27.09 & 2.11 & 10.1 & 50.50 \\
\hline 2016-17 & 20 & 38 & 23 & 10.92 & 8.21 & 33.01 & 2.71 & 13.08 & 54.50 \\
\hline $2017-18$ & 50 & 63 & 23 & 15.01 & 11.93 & 25.82 & 3.08 & 8.99 & 37.46 \\
\hline Mean & 90 & 126 & 22 & 11.94 & 9.31 & 28.64 & 2.63 & 10.72 & 47.49 \\
\hline
\end{tabular}

RP - Recommended practice, FP -Farmer's practice

Table.3 Economic analysis of demonstration and farmers practices

\begin{tabular}{|c|c|c|c|c|c|c|c|c|c|c|}
\hline \multirow[t]{2}{*}{ Year } & \multicolumn{2}{|c|}{$\begin{array}{l}\text { Cost of } \\
\text { cultivation }\end{array}$} & \multicolumn{2}{|c|}{ Gross return } & \multicolumn{2}{|c|}{ Net return } & \multirow{2}{*}{$\begin{array}{c}\text { Additio } \\
\text { nal } \\
\text { cost }\end{array}$} & \multirow{2}{*}{$\begin{array}{c}\text { Additiona } \\
1 \text { net } \\
\text { return }\end{array}$} & \multicolumn{2}{|c|}{$\mathrm{B}: \mathrm{C}$ ratio } \\
\hline & $\mathrm{RP}$ & FP & RP & FP & $\mathrm{RP}$ & FP & & & RP & FP \\
\hline 2015-16 & 23928 & 21936 & 50465 & 39729 & 26537 & 17793 & 1992 & 8744 & 2.1 & 1.81 \\
\hline 2016-17 & 29878 & 25936 & 57876 & 43513 & 27998 & 17577 & 3942 & 10421 & 1.94 & 1.68 \\
\hline 2017-18 & 29675 & 26680 & 45030 & 35790 & 15355 & 9110 & 2995 & 6245 & 1.52 & 1.34 \\
\hline $\begin{array}{l}\text { Total } \\
\text { Mean }\end{array}$ & $\begin{array}{c}27827 . \\
00\end{array}$ & $\begin{array}{c}24850 . \\
67\end{array}$ & $\begin{array}{c}51123 . \\
67\end{array}$ & $\begin{array}{c}39677 . \\
33\end{array}$ & $\begin{array}{c}23296 . \\
67\end{array}$ & $\begin{array}{c}14826 . \\
67\end{array}$ & $\begin{array}{c}2976.3 \\
3\end{array}$ & 8470 & 1.85 & 1.61 \\
\hline
\end{tabular}

RP - Recommended practice, FP -Farmer's practice, B: C Ratio -Benefit cost ratio.

\section{Extension gap}

The extension gap showed an increasing trend. The extension gap ranging between 2.11 to $3.08 \mathrm{q} / \mathrm{ha}$ (Table 2 during the period of study emphasizes the need to educate the farmers through various means for the adoption of improved agriculture production to reverse the trend of wide extension gap. The trends of technology gap reflected the farmers' co-operation in carrying out such demonstration with encouraging results in sequent year. The technology group observed may be attributed to the dissimilarity in soil fertility status and weather conditions.

The technology index showed the feasibility of the evolved technology at the farmer's field. The lower value of technology index more is the feasibility of the technology demonstrated (Sagar and Chandra, 2004). As such reduction in technology index from $50.50 \%$ during $2015-16$ to $37.46 \%$ during 2017-18 exhibited the feasibility of the demonstrated technology in this region.

These results confirm the findings of crop technology demonstration on oilseed and pulses crops by Yadav et al., (2003) and Lathwal (2010).

From the above findings it can be concluded that use of scientific method of chickpea cultivation can reduce the technology gap to a considerable extent which will lead to increase productivity of chickpea in the district. Moreover extension agencies in the district need to provide proper technical support to the farmers through different educational and extension methods to reduce the extension gap for better pulse production in the district. 


\section{References}

Anonymous (2016). Directorate of economics and statistics, Krishi Bhavan, New Delhi.

Kirar, B.S., Mahajan, S.K. and Nashine, R. (2004). Impact of technology practices on the productivity of soybean in FLD. Indian Res. J. Ext. Edu., 5(1): 15-17.

Krishna Kant, Kanaujia, K.R. and Kanaujia, S. (2007) Role of plant density and abiotic factors on population dynamic of Helicoverpa armigera (Hubner) in chickpea. Ann. Plant Protec. Sci., 15: 303-306.

Lathwal, O.P. (2010) Evaluation of crop demonstration on black gram in irrigated agro ecosystem. Ann. Agric. Res., 31: 24-27.

Raj Krishi (2016-17). Commissionerate of Agriculture, Rajasthan- Jaipur

Sagar, R.L., and Chandra, Ganesh (2004). Frontline demonstration on sesame in West Begal. Agric. Extn. Rev., 16: 710.

Samui, S.K., Moitra, S., Ray, D., Mandal, A.K. and Saha, D. (2000). Evaluation of frontline demonstration on groundnut. J. Indian Soc. Costal Agric. Res., 18: 180183.

Teggelli, Raju G., Patil, D.H., Naik, Ananda, Zaheer Ahamed, B. and Patil, M.C. (2015). Impact of front line demonstration on the yield and economics of pigeonpea in Kalaburgi district of Karnataka State. I.J.S.N., 6(2):224-227.

Tomar, R.K.S. (2010) Maximization of productivity for chickpea (Cicer arietinum L.) through improved technologies in farmer's field. Indian J. Natural Products \& Resources, 1: 515517.

Verma, Deependra Prakash (2013). A study on impact of front line demonstrations on pulses by Krishi Vigyan Kendra, Panna M.P. M.Sc. (Ag.) Thesis, Jawaharlal Nehru Krishi Vishwa Vidyalaya, Jabalpur MP.

Yadav, J.K., Singh, H.L. and Kumar, R. (2003) Determining selection components in chickpea (Cicer arietinum L.). Plant Arch., 3 (1): 125128.

\section{How to cite this article:}

Shayam Das, Pradeep Pagaria, B.R. Morwal and Manpreet Singh. 2018. Yield Gap Analysis for Chickpea (Cicer arietinum Linn) Through Cluster Front Line Demonstration under NFSM Scheme in Barmer District of Rajasthan, India. Int.J.Curr.Microbiol.App.Sci. 7(09): 129-133. doi: https://doi.org/10.20546/ijcmas.2018.709.017 